\title{
DIE AFBUIGING VAN CALVYN SE DENKE IN DIE 17e EEU
}

\author{
L.F. Schulze, Drpartement Dogmatiek, Pl'vir ('IIO)
}

\section{ABSTRAC:T}

The period of the Reformation was in cerlain aspects a lonely beacon in the cullural history of Western cinilization. This fact is illuminated by comparing the anti scolastic sland of Luther and Cialom, and especially Calvin's trinilarian view of revelation with its enswing knowledge of ('od with the views of Perkins and Ames. in whose works tendencies towards a nalural knowledye of God become discernable. Though the language of the later theologians remains "calvinistic", yet there is a clear shifi of accent in the whole theological structure of their works and a growing emphasis on subjectivity.

\section{INLEIDING}

Dic: Reformasic is 'n ecnsame bergspits in dic geestesgeskicdenis van die Westc (Van der Woude, 1964:5-6). Om dit aan te toon word Calvyn as vertecnwoordiger van dic Reformasic, genecm en kortliks met twec invloedryke Engelse tcolö uit dic laat 16 de en vrocê 17 de ceu vergelyk: $W$. Perkins (1558-1602) en W. Ames (1576-1633). Eersgenoemde was die iuvloedrykste Engelsc tcoloog van die regeringstyd van Elizabeth (Breward, 1970, Edicorial Preface, p. XI), (erwyl William Ames in hesonder sy stempel op die Nederlandse tcologie afgedruk het toc hy in sy produktiefste jare in Fiancker geclosecr het.

Die punt van vergelyking word tot net een beperk, hocwel daar vecl mecr aspekte is wat vergelyk kon word. Die fasel wat by clkc teoloog kortliks teties gestel en dan samevat tend vergelyk sal word, is dic kennis van God. Hicrdic kentcoreticse vergelykingspunt is gekics omdat dit van grondleggende belang is.

'n Vergelyking van Calvyn met Perkins en Ames betreffende hicrdic punt sal aantoon dat daar by laasgenocmde twec 'n akscntverskuiwing plaasgevind het. Dit sal ook hopelik blyk dat 'n aksentverskuiwing in dic tcologic gewoonlik nic' 'n middelmatige saak is nie maar'n simptoom van 'n verskuiwing in uitgangspunt, wat dic visie op dic hele dogmatiese spekt rum raak. 'Ten slolle sal 'n poging aangewend wold om dic mocilike vraag te beautwonrl waarom hierdie afhuiging in die 17de ceu plaasgevind het en dic brlangrikhcid van hicrdic ontwikkcling vir ons aan te toon.

Koers, 18(1) 1983 


\section{Afbuiging van Calvyn se denke}

Enkele implikasies van dit alles kan reeds in hierdie sladium uilgespel word en horf nic later herhaal te word nie. I. Ons moct kriticser na ons ric terminologie kyk en veral na die betekenis en reguerdighaarheid van die term (ialininisme. ( )ns liet hierdie term in die verlede soms ic argeloos geloruik met die fout iewe veronclerstelling dat 'n reglynige ont wikkeling van (ialvyn se teologie in clić van sy navolgers aanwesig is. 2. Ons sal wecr oog moet kry vir die uil gangspunt en bedocling van die Reformasie. I hit sal ons hrlp om were die Belyrlenisskrifte as podukte van rlie Reformasie beter Ie begrypen inctecn dus ook te begryp waar ons in die huidige problemalick staan. D)i beteken om dic belydenisskrifte te verstaan in dic lig van hulle ont staanstycl en om hulle dus juis nic in die lig van my cic stanclpumt te interpretcer nic, l. i. om hulle te laat sê wat ek graag daarin wil hoor nic. l,aasgenocmole is 'n berouc gebruik, eg menslik en ook begryplik maar daarom nog nic ecrlik nic. So 'n teruggang betcken nic 'n idcalisering van dic Relormasic of 'n vcrabsolutering van dic konfessic nic maar wrl 'n positiewe standpuntinname op dic basis van dic belydenis. Inderdaad, ons staan hier in 'n hermencutiesc sirkel, waarin alle ander gelowiges op hulle cic manier ook staan, 'n sirkel wat alleen deurbreck kan word wanneer eerlike eksegese 'n oorweldigende getuienis teen jou standpunt sou gee. So bly die Skrit dic laastc norm naar dan dic Skril en nic my interpretasic van dic Skril nic.

\section{DIE KENNIS VAN GOD}

(alvyn: Dic cerste twee bocke van dic Institusic handel oor die keunis van (God; die ecrste boek oor die kennis van God die. Skepper en bock twee oor dic kennis van God die Verlosser. Hy volg hierin dic orelen van die Skrifen van dic $\Lambda_{p}$ ostolicum. Ily sć:: "Aangesien God sowrl in die skepping van die wêreld as in dic algemene lecr van die Skrif eers ecnvoudig as 'n Skepper verskyn en claama as 'n Verlosser in Christus, ' vloci hieruit 'n twecvoudige kennis van Hom voort" (Inst. 1,2, I, vry vertaal). Hierdic segswyse van (alvyn is ietwat dubbelsinnig. (Geen wonder dus dat dit aanleidling gegee hel tot die foutiewe gedagle dat hy hier 'n skerp onderskeiding tussen natuurlike en geopenbaarde (Godskennis maak nic. D)aarmec saam sou volgens hierdie interpretasie van Calvyn die regte orrle van ons kennis dan só wees: ecrstens 'n naluurlike kennis van (jorl clie Skepper en tweedens 'n geopenbaarde kennis van (God dic Verlosser. I) it is cgler fout ief. Hoewel die 'tweevoudige kennis' op God die Skepper en God die Verlosser slaan, implisecr dit nic 'n natumrlike kennis van God die Skepper nic. Calvyn sế

\footnotetext{
1 primum (creator) drinde (redemptor).
} 


\section{Schulze}

uitclukklik dat ons kennis van die Skepper soneel uil die skepping as uit dic Skrif kom². Dit le ook duidelik in dic verband van die ecrste bock van dic Instilusic. Dic openharing van (God die. Skcpper is dus in 'n sckere sin ook 't wecvoudig': in clic natuur en in die Skrif of, as u wil, algemeen cn besonder.

Hy bespreck dan ecrstens dic openharing van God in dic natuur. Van kardinale belang is die algemene beskrywiug wat hy gec van ons korresponderende kennis van (fod uit hicrdic openlaring:

"daardic cenvoudige en primitiewe kemnis waartoc die blote verloop van dic natuur ons sou gebring het as Adam staande gebly het" $(1,2,1)$.

l,et op dlic hipoteticse formulering: ons son kennis van God uit die natuur kon kry as Arlam staande gebly het! Calvyn gaan dan tog hicrdie openbaring wal in dic versı and van die mons as semen religionis $(1,3) \mathrm{cn}$ in die skepping en onderhouding van die wêrelel $(1,5)$ tot ons kom, bespreck. Hy doen dit omdal God cenvoudig in sy werke sigbaar word; dic openbaring is dáár cn dit kom op die mens af. Maar dic uitwerking van die openbaring is nic mecr ware (iodskennis nic. Adam het immers uic staande gebly nic. Daarom word dic openbaring misken, verdraai, vermenslik. Die openbaring in clic verstand van dic mens lei nic tot kennis en aanrocping van (ood nic maar tot algorlery. Dic menslike verstand, waarin die semsus divinitatis onuit wishaar ingegr if is, word dic vrugbaarste fabrick van afgode. ()ok dic opcubaring in die skıpping en onderhouding van dic wêreld, sovecl 'lıclder laumpe' wat die glorie van die. Skepper verlig, word deur die mens in ongeregtigheid onderdruk en bring ons nic tot die ware kennis van God nic. Jaatom het die openbaring in lic natuur net ecn cnkele, negatiewe resultaat: dit stel dic mens skuldig en sonder verskoning omdat hy God nic geken en gedien het soos hy moes nie.

Ondertussen is dit belangrik dat onthou word dat Calvyn tot hicrdic slotsom kom nic as gevolg van ' $\mathrm{n}$ empiriesc ondersock nic maar vanuil dic. Skrif - as ckscgect van Rom. 1:19,20. Dit is 'n uitspraak vanuit die Skrif. Dic Skrif vertel ons van (jod sc openbaring in dic natuur en veroordcel ons kortsigtigheid en verstoktheid. Dit is immers die Heilige Gecs wat deur die Skrif alle natuurlike kemuis van (jod as afgorlies brandmerk en si dat dic lifesiērs "soncler Gorl" was (Ef. 2:12) totdai hulle van die evangelic gelecr

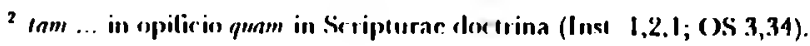




\section{Afbuiging van Calvyn se denke}

het wat dit heteken om dic ware Gorl te dien $(1,5,13)$.

Dir Skrif, daardic 'betcr hulpmiddel' wat God gegec het, lei ons tot ware Godskennis. "Dic cerste stap in warc kennis worl gerloen wannerr ous eerbiediglik die getuienis wat (Gorl na sy welbehawe van Homself daarin (d.i. in clie Skril - L.I.S.) gegec het, omhels" (I.6.2).

Wic God dus buite dic Skril om wil sock, sal misluk. hoc hard die mens ook probecr, want hy sock in 'n verkeerde rigting. Dic Skrif is dic 'bril' waarcleur' ons God in die natuur reg kan sien. Dit beteken: in dic. Skrif sien ons God die Skepper, wat ons in dic natuur moes gesien het maar nic gesien het nic. In om God in dic Heilige Skrif te sien en te ken - claarvoor is elie verligiende werk van die Heilige Gecs nodig. Wannecr Calvyn in I,8 dan tog deur natuurlike argumente die uniekheirl en gesag van dir Skril wil aantoon, is dit nic berlocl as 'n weg waarlangs 'n me'ns tol aanvaarling van clie Skı il kan kom nic, maar gec hy aposteriorics 'n betoog clat gelool in dic Skı if nic dwaas is nic. 'l'rourns, hy begin die hoofstuk dewr op te merk rlat geen menslike argumente enige krag sal hế as dit nie deur 'n hoüre getuicnis ondersteun word nic. Hy sluit dic hoofst uk af deur onomwonde te stel clat dit "dwaas is on te probecr om aan ongdowiges te bewys dat Skril rlic Woord van (iod is", want dit "kan ons nie weet nie behalwe deur dic gelool" $(1,8, I 3)$.

Aangesien dic Gecs deur die Woord die geloof werk. ken ons God die Skepper deur dic gelool. Dic geloofskennis is nic vir alle mense algemen tocganklik nic maar is 'n "unickc voorreg wat God allecen an sy uitverkorenes verlecn, wat Hy van die res van dic mensheirl afsonder" $(1,7,5)$.

Dic openbaring van (God dic Verlesser kom tot ons in_Jesus ('hristus soos Hy in dir Skril as dic Becld van dic Vader aan ons voorgchou worrl $(2,9,1)$. licrdic kennis van Cod is as 'I ware 'praktics', want dit is 'n kennis nir van hor God in Homself is nic maar hoedanig Hy tccnoor ons is. Sonder hierdie" kennis is claar geen vrommleid, geen geloof, gecn ware kennende verhouding tot God moontlik nic. Aangesien ons allecn kan weet hoe (jod tecnoor ons is as ons Hom sion soos Hy Hom in Cluristus bekend maak (naamlik as 'n genaclige Vader), volg dit dat ons (fod allecn waarlik in Christus kan ken (vgl. 2,6,2). I) it is dus slegs wanncer ons Gocl as Varler in Christus leer ken het dat ons Hom ook as ons Skepper leer ken (vgl. HK Sondag 9 en 10; vgl. Inst. 2, (5.1).

Ons sluit hicrdic baie kursoriese oorsig met twee opmerkings al. 


\section{Schulxe}

1. Let op dic volkone trinitariese funclering van ons kennis van God by Calvyn. () ke ken God as ons genadige Vader wannecr ons Hom in Jesus Christus sien cleur die getuienis van die Heilige Gees. Alle ander kennis is afgodies en vals. Anders gesê: Ons ken God glad nic, bchalwe as ons I Jom só deur sy Woord leer ken. Christus kom dus nie vir ons inligting byvocg by 'n God wat ons recels deur clic natuurlike openbaring leer ken het nic. Dit was rlic Roomse lecr wat in die $17 \mathrm{de}$ ecu in Protestantse kringe weer sy verskyning mank. Nec, vir Calvyn trek dic hele opcnbaring van God in clie Christus van dic Skrifte saam. In Hom het dic. Vader sy hart aan ons bekend gemaak en ook sy hande en sy vocte (d.i. sy werke).

2. Ons ken God nic soos ons natuurlike voorwerpe ken nie. Hy is nic 'n objek van kennis nic maar 'n l'crsoon wat ons lecr ken as ons cleur dic majesteit van sy Woord oorwelelig word. Ons kennis van God is dus kommunikatiewe, persoonlike kennis - wel rasionecl maar nic rasionalisties, abstrak en koud nic maar ecrder 'cksistensicel' ('Torrance, 1964:147-154).

\section{PERKINS}

By Calvyn se oorlye (in I564) is Perkins recds ses jaar oud. Hy staan dus chronologies ná aan Calvyn. Hy staan ook Icerstellig ná aan Calvyn. 'Tog het die klimaat, dic aanpak en clic opset van die tcologic by hom verander. Gevolglik vind ons ' $n$ bepaalde ambivalensie in sy uitsprake: aan dic ecn kant hoor jy dic taal van Calvyn, aan dic ancler kant hoor jy vrecende geluide.

Dic verskil in klimaat word in rlic struktuur cn tcmatick van sy werke wecrspicèl. In sy Katcgismus, geskrywe aan alle "ignorant pcople that desire 10 be inst ructed" en getitcl The foundation of C'hristian religion gathered tn/o six principles, word die Christelike Icer in dic volgenele beginsels saamgevat:

1. Cool is dic Skepper en Regecreler van alle dinge.

2. Dic mens is 'n sondaar en dic ewige verdocmenis skuldig.

3. Christus het deur sy kruisclood en geregt igheid alle dinge vervul wat vir die verlossing van dic mensheid nodig is.

4. 1)cur clic geloof allecn word ons geregverdig en geheilig en so deelgenole 


\section{Afbuiging van Calvyn}

ann Cluristus en sy welrlade.

5. Die gewone midclele waardeur ons geloof verkry, is dic prediking, sakraincute en geloed.

6. Alle mense sal liggaamlik opstaan, die gelowiges tot die lewe en dic ongelowiges en verworpenes tot dic hel se smarte.

Dic matcriaal is Rctormatories, maar dic struktuur van dic werk is opvallend anders as dic van kategismusse uit dic: Reformasic. I aasgenocunde is rondom die (icloofsbelydenis, die wet en die gebed gelout. Hicrdic opset ontbreck by Perkins. Allecn die wot kom ter sprake in dic verklaring van dic vicrde beginsel, maar dan nic as recl van danklaarheid nic maar as voorbereieling vir dic ontvang van dic geloof. Dic swaat (epunt van dic werk le duidelik in die verk laring van beginsels $4 \mathrm{cn} 5$, waar dit gaan om die tor-ciening van die heil en dic midelele daartor.

Sy bekendste werk, $A$ golden , haine, volg min of nees dic gang van sy Katcgisınus maar is by die licilst oc-ciening opdic dekrete van verkicsing en verwerping tocgespits. Dic volle titel se vir ons duidelik dat dic hele teologiese aanpak verander lect: $A$ (iolden (Chaine: or, the Descriphon of theolngr. Containing the Order of the Ciauses of Sinkation and Dammation, Acrording to Gods Word.

Let op dat die besklywing van dic Icologic hier wesentlik opgaan in die beskrywing van die goue ketting van oorsake van dic saligheiel en die verdocmenis. Die trant van dic uitecnselling is glashelder, baic logies en redenerend, lerwyl daar dikwels teiwerpinge beantwoord word. Dic opset en ook dic grafiess voorstelling van dic 'gour ketting' is dlcur Brya sc. Summa geinspirecr.

The whole Trentise of the Cases of Conscience, distingmished inlo lluree Bonks is 'n lywige werk van 635 bladsyc waarin pastorale sorg aan clie mens gegec word rakende sy gewete, sy verhouding tot God en sy verhouding tot dic naaste. Die uilcensetting is geweldig verbesonder en logies belogend met ryke Skrifbewyse wat as inclividucle tekste in die loop van die betong ingevoen word. Die geheelindruk is dat die mens hicr ont saglik belangrik word en dat hy kasuïst ies onderrig moet word om in sy tocpassing van die wet reg te kan lewe. Dit klop mel l'erkins se omskrywing van dic teologie in die cerste hoofstuk van $A$ (iolden (haine:

"l'heologie is the science of living blessedly for ever". 


\section{Schulz.e}

Perkins praat nog duidelik die taal van die Reformasie. In die cerste hoofstuk van $A$ (iolden Chaine hoor 'n mens duiclelik dic cggo van dic opcningscksic van Calvyn se Institusie, waar dic nouc verbondenheid van ( 'orlskennis en selfkennis ter sprake kom. Perkins skryf:

"Theology is the science of living blessedly for ever. Blessed life ariseth from the knowledge of God and therefore it ariseth likewise from the knowledge of ourselves, because we know God by looking into ourselves" (Breward, 1970, 177).

Nes (alvyn kan Perkins ook dic natuturlike Godskennis met 'n beroep op Rom. 1:19 en 20 veroordecl. So'n duidelike uitspraak kry ons in hoofstuk 12 van A Golden (haine, waar Perkins oor dic crfsoncle handel. Om die crfsonde en sy uitwerking op die menslike natuur beter te verstaan moct ons dric omstandighede in ag necm, sć Perkins. Nou is die eerste van hierelie dric vir ons van belang, naamlik "How much of Gods image we yet retaine". Hicrop antwoord hy:

"I. In the mincle. The remnant of Gods image, is certaine notions concerning good en evill: as, that there is a God, and that the same God punisheth transgressions: that there is an cverlasting life: that we must reverence our supcriours, and not harme our neighbours. But cven these notions, they are both generall and corrupt, and have none other use, but to bercave man of all excuse before Gods juclgement seate. Rom. 1-19,20" (sitaat by Chalker, 1961:101-102; vgl. Breward, 1970:192).

Die problecm ly Perkins is dat hy vanwee 'n verandering in teologiese klimaat hicrelic 'Cereformecrde' taal nic kan vollou nic. Dit is spocelig duiclelik dat dic 'ncgatiewe' funksic van dic natuurlike (Godskennis, wat Perkins l,inne die konteks van dic erfsonde duidelik uitspreck, by die Godslecr cintlik vergetc raak - juis dáár waar dit vir Calvyn van kardinale bclang was. Dit word dadclik duiclelik as ons sy Kategismus oopslaan. In sy verklaring van die cerste beginsel van dic Christelike gelool word ons reeds getref deur die cienaardige formulering van clic cerste vraag: "What is Godl?" Maar dis veral die volgende dric vrac en ant woorde wat vir ons hier brlangrik is.

"Q. How clo you persuade yourself that there is a God?

A. Beside the Iestimony of the scriptures, plain reason will show it

(). What is one reason? 


\section{Afbuiging van Calvyn se denke}

A. When l consirler the wonderful frame of the world, me thinks the silly creatures that be in it could never make it. Neither could it make it self and therefore besides all these, the maker of it must be God ... Rom. 1.20 ;

Q. What other reason have you?

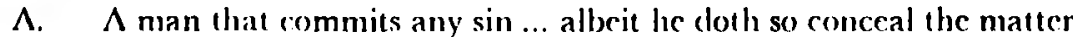
that no man living know of it, yet oftentimes he hath a griping in his conscicner and feels the very flashing of hell-fire; which is a strong reason to show that there is a God before whose judgement seat he must answer for his fact. Rom. 2:15; (ien. 3:8, 10; 42:21" (Breward, 1970, 149; silaat verkori).

Later in dicsclfele afdeling, wanneer dit oor dic voorsienigheid gaan, kom dicsclfde: argumentasic terug:

"Q. How know you that God governeth cvery particular thing in the world by his special providence?

A. 'To omit the scriptures, I sce it by experience. Meat, drink and clothing, being void of heat and life, could not preserve the life of man unless there were a special providence of (Goll to give virtue unto them. Matt. 10:30; Prov. 16:33; Lev. 26:26; Malt. 4:4" (id.:150).

Dit is die enigste vraag oor dic voorsicnigheid in Perkins se Kategismus. I) is dudidelik dat die vraag nie, soos in dic Heidelberger, bimuc dic kontcks van dic troos gevra word nic. Kennis van dic voorsienigheid is, soos Godskennis in die gehecl, vir l'erkins geen geloofskennis nic maar'n algemecn toeganklike, ncutrale e'n rasioncle kennis waarıc alle mense kan kom. Daarom ook dat die ou (iodsbewyse van die: Skolastick weer hicr om die: hock vir ons kom locr!

Diesclfite tendens vind ons in $A$ (olden (haine. ()ns kan wat hicrdic werk hetref, met die bonclige en m.i. korrekte samevatting van Chalker volstaan (1961:100-101): "But it is soon apparant that Perkins does not mean quite the same thing by knowledge than Calvin dicl. For Perkins immediately plunges into his doctrine of God, which includes such items as the nature of God, the life of God, the glory and blesssedness of God the Persons of ile Godhead, the decrees 


\section{Schulze}

of (iod, and predest ination and creation by God (C)laps. ii-vii), and yet the: knowledge of this God does not result in the blessed life which Perkins promises. Even when to this knowledge of (iod is adcled the knowledge of man as sinner (Chaps. ix-xiii) and of Jesus (Christ as the one who takes a way the pumishment of $\sin$ (Chaps. xv-xviii), this blessedness ches not result. It is only when the miraculous quality of Taith is added to or qualifies this knowledge (Chap. xxxvi) that the blessed life follows. But in the order of salvation this knowledge does play an important, yet ordinarily indispensable, part. How, then, do men acquire it? Naturally it would serm Perkins hegins chapter awo with this observation:

I'hat there is a God, it is cevident: 1. by the course of nalure: 2. by the nature of the soule of man: 3. by the distinction of things houest and dishonest: 4. hy the terror of ronscience..."

In sy Tirntise of Cinnsrience is Perkins uitgesproke oor dic natuurlike Codskemnis col bevest ig hy wat ons recds uil sy Kalegisınus afgelei hel en wal C'halker in d (;olden (ihaine aantoon. In genoconde werk behandel Perkins dic (Godskemuis in die begin van dic I weede bork. Dic cersle vraag onr dic lema "()) the Godhead" is dan: "Whether there be a (iodl". Hicroor beloog hy (1606):203-204) dan dic volgende:

"And for our loctter knowledge: and assurance of the I ruth, we are: to remember his much, that (iod hath given unto man a threefold light: the one of nature, the other of grace, and the thircl ol gloric. And loy these, as by so many degrees of knowledge, the minde being inlightencel by God, recciveth direction in the truth of the Godhrad, both for the present life, and for that which is to come.

If it be demaunded, in what order God hath reveiled this ligh! unto man: l.answer, that the light of nature setves to give a beginning and preparation to this knowledge: the light of grace (d.i. die Skrif L.F.S.) ministers the ground, and gives further proofe and evirlence: and the light of glory (d. i. dic hemelse heerlikheid - L.F.S.) yeclds perfection of assurance, making that perfectly and fully kuowne, which by the former Ilegrecs was hut weakly and imperfectly comprehended".

In dic 'lig van dic natum' word dan in twaalf bladkye "live dislinc: arguments to proove that there is a God" belianclel (p. 204-21 (b). I)ic I weede recks bewyse kom uil dic Skril, die 'lig van die genacle', en wou d in 'n enkelc bladsy be-handel (p. 216-2I7). Weer cens word dic lig van dic natuur 


\section{Afbuiging van Calvyn se denke}

veronderstel waarop die genadelig as "n further confirmation" voortbou:

"For the light of nature, is oncly a way or preparation of fait h. But this light (d.i. die genadelig - L.F.S.) serves to beget faith, and causeth us to belecve there is a God" (1601:216).

Hicrdic 'gelool" is egter net " 10 belecve there is a (iod". I )it bly in die alost rak rasioncle steck. Hier word nie die openharing van God se vaclerlike guns in Jesus Christus deur die getuicnis van die: Gees belıandel nic maar weer 'natuurlike' argumente vir die unickheid van die Skril. 1'erkins nocm dric "dist ince proofs of the point", namlik 1. uitdruklike get nicnisse wat dic bestaan van Cod aandui; 2. dic vervulling van professicé cn openbaringe sclfs ceuc naclat dit gegec is; 3 . dic wonders, wat dic gang van dic natuur oortref. Docl van die wonders is "to shew that there is an absolute and almightic power: which is the author of nature it selle, and all naturall things, and ordereth both it and them, according to his pleasure"' (Perkins, 1606:217).

'Iog sou ons Perkins 'n onreg aandocn as ons hom as 'n voorstander van dic natuurlike l cologic sicn. 'Terwyl die natuurlike teologic wel weer 'npositieue faktor word, wil hy log essensicel bly staan waar Calvyn gestaan het. In $A$ declarntion of the True Manner of Kinowing Christ C'rurified (John Legalt. London, I6.35) hoor'n mens weer dic taal val Calvyn:

"Il we would know the truc (jod aright, and know him to onr salvation, we must know him oncly in Christ rrucified. God himself and his owne. Majestic, is invisible ... and he is revealed to us oncly in Christ, in whom he is lo lue scene, as in a glasse. For in Christ he setteth forth and gives his justice, goodnesse, wisdome, and himself wholly unto us ... Therefore wec must not know God, and secke him any where clse hut in Christ" ... (Chalker, 1961:109; sitaat verkort).

I ic problecm is slegs dat hicrdic taal nic mecr oortuig nir: dic integrasic van visie: het cerens op dic tcologiese pad verlore geraak.

\section{AMES}

Ames l'erkins se lecrling, William Ames, sit hicrdie tenclense van sy lecrmerster voort.

In sy bekendste werk, Ihe Marrove of Sacred Divinity, Drawne out of 
scinulze:

the Ioly Sirriphures, and the Interpreters thereo/, and Bromghl into Method, behandel Ames in hoofstuk 4 die wese van God en in die volgende hoofstuk die Iriniteit. Wat die bron van ons Godskrmnis is, word nie lier uitchuklik gesê nic, word dit duidelik dat die kenbron van dic wese van God dic matnmr is, ter wyl dic kcubron van die Trinitcit dic Skril is. Hy sê: "By the creation God is kuown, but not God the lather, Sonne and Holy Spirit, because that eflecting power whereby the worlel was created, pertaines to the essence of Cod, and not to his personall subsistance (p. 35; sitaat by Chalker, $1961: 107)$

Anders as by Perkins word hicrdic natuurlike. Godskennis nir merr as afgoclies afgewys nic; intecndecl, hicedic kemnis vorm die basis waarop dic kennis van God in Ghristus verstaanbaar word:

"Firom the consideralion of Creation our Faith ascencleth above all the order of nature, and apprehends the light of the Glory of God, to be shewed forth in the Face of Jesus (Christ, because it is God, who commanded the light to shine out of darkncsse" (p. 39).

Maar Ames bedoel met hicrdie Skriftumrlike kemnis icts anders as Calvyn. Soos ons by Perkins se "light of grace" recds 'n algemene geloof dat daar 'n ('ocl is, opgennerk het, so bied die Skrif onk vir $\Lambda$ mes' 'n ueare kcmnis van (God, maar algemeen toeganklik, want hicrdic ware kemnis word gedecl deur dic grelowiges, "unlselicvers, hereticks, apostates, and the devills themselves" (Marroes. 221; vgl. Chalker, 1961:110). ()mdat die Skrif dic bron van hicudic kennis is, is clit in alle opsigte volkome, maar dit is nie saligmakende: kemuis nic.

Ames kan hierdic opvatting handlaaf mede omdat dic menslike siel nou in hokkies ingedrel word: dic sctel van hicrdie kennis is die menslike versıand ('human understanding'), terwyl die sctcl van dic geloof die incnslike wil is. Dic: getuicnis van dic Heilige Gecs is 'n noorlsaaklike voorwaarde vir die ware geloo/ maar nic vir hicrdic uerstaan van dic evangelic nic, want "there is nothing at alt recpuired, cither in respert of the things to be belicved, or in respect of the cause and way of locliceving, which is not found in the. Sicripture" (id.).

Ook Ames het 'n lywige werk oor dic gewetc geskryf, 'n kasuistiese sturlie van alle denkhare gevalle waaroor die gewelc uitsluilsel vra. llicrin keer ook dir sillogistiese redenasie terug wat so tipies van die 
Afbuiging van Calvyn se denke

Skolastick was.

\section{SAMEVATTING}

Wat lict verkecrd geloop? 'n Mens is genoorlsaak om hicrdie vraag te stcl, want dic Irit dat daar' $n$ kinkel in dic kabel van dic Reformatoriese tcologic gekom luct, is sonder meer duidclik. Dit is 'n vraag waarop kerkluistorici seker meer afdoende kan ant woord. Teroorweging moct ons dic volgende in gerlagle hou.

Dic felle reaksic van $\mathbf{L}$,uther teen die Skolastick was van korte dumr. In sy 97 steilinge Disputatio comtra seolasticam theologiam toorn hy 1 cen "dic verdomde heiden, Aristoteles" en stel: "dic hele Aristoteles is vir dic teologic wat die duistcrnis is vir clic lig" (stclling 50). In 'n ander stclling sê hy:

"Gecn enkele sillogisticse vorm is in goddelike sake van krag nic. Indien 'n sillogistiese vorm in ('odclelike sake van krag is, clan sal rlic artikel van dic 'Triniteit geteéét word in plaas van gegló word" (art. 49).

Wannecr hy egter later aan Mclanchthon opdrag gec om dic skole tc reorganiscer, word $\Lambda$ ristoleles so gaandeweg weer ingevoer omdal datar gecn alternaticf was nic. Aan die begin van dic I 7de cen was Aristoteles weer die onbel wisbare outoritcit - ook te (ambridge, waar Perkins cn Ames gestudecr bet. Boonop) was hier ook die Ramistiese: logika geweldig populer. Die opvolgers van die Relormasic mors dus maar veg met dic wapens wat tot luulle beskikking was, naamlik dic wat uil dic arsenaal van dic skolastick voorsien is. Die terugkecr na die skolast iek was cgter cerder 'n.simpromm as 'n oorsaak van dir verval van dic (iereformecrde teolegic.

(ilobaal genome was die I 7de ceu anti-skolasties ingestel. Nic meer dic dednkticwe redenasic oor en beskouing van dic syn (onlologic) is die inode nic maar cmpiries-indukliewe ont clekking van nuwe waarlocde, 'leite' in die kosmos. Dil was tog die ceu van Bacon, I)escartes, Hobbes en luble medestanders. Dil was dic cen waarin die Verligting hegin vorm aannecm het, dic ecu waarin dic mens so belangrik geword het. Gecn wonder dus dat dic besondere openbaring van God vir die neutralc (cu outonome?) menslike rede algemern locganklik word en dal dic tcologic in hicrelic ecu van cupiriese ontelekking moct saamspecl om dic vastheid van die heil (resp. dic sekerheid van dic gelool) in die cic lewe empiries vas tr stel nie. Daar mag mecr redes wees. Ons volstaan met hicrdic iwec.

Dic aksentverskuiwing was cgler slegs simptorm van 'n verskuiwing in 


\begin{abstract}
Schulze
tcologiese uitgangspunt. Dic humanum het in elic 17de ceu te belangrik gewotd om verontagsaam te word. Die vroom mens word die sentrale punt. Dit is nie meer die openbaring van die drie-enige God wat in Christus deur die werking van die (jees die mens se ore deurboor en hart aanraak en so die: geloof skep nic. Nec, dic openbaring verloor sy adres; dit word 'n geopenbardlıcid, tocganklik vir dic mens se uitnemende rede. Maar dit werk gecn heil nic. Daarby moct dic geloof kom, 'n wilsakec van dic mens waartoc hy hom kan voorberci (Ames) en waardeur $h v$ wil om Christus vir lomself toc te cien, nat uurlik nic sonder dic Heilige Gecs nie maar tog met dic aksent op dic menslike wilsakte.
\end{abstract}

Inderdaad, as dic openbaring sonder dic Gees geken word, dan is Cod nie meer voldoende Getuic van Homself en van ons heil nie. Dán word die mens op homself teruggewerp. En dan is dit maar 'n paar trec' verter waar dic moderne teologie staan, wat van dic gesag van dic openbaring niks meer wil weet nic en wat die mens uit sy kollektiewe historiese ervaring 'n gorlsdiens as sock micldel laat ontwerp of die Christendom bloot sien as cen van dic baic: paaic wat na Rome lei. Hićr hel die mens net nog 'n bietjic loclangriker geword as in die ceu van dic begin van dic telcskoop en mikroskoop.

Dic hunıanisme bring altyd 'n aksentverskuiwing in dic teologie: die heil word nic meer in dic objekticwe werk van God nic maar in dic subjekticwe aksie van dic mens verwortcl. Of hierdic subjekticwe aksic nou rasioncel is cn of dit voluntatief is en of dit emosionecl is, maak nic vecl verskil nic, dis sovecl variasies op diesclfcle tema. Ons sien by Perkins en $\Lambda$ mes die rasionalist iese en die volumtaticwe subjektivisme hand ann hand. Maar hier is dit heed individualisties gesicn. In ons ecu word dic voluntaticwe realisering van clic heil nic mecr individualisties nic maar kollekticf gesien (politicke tcologic).

Dic afbuiging van dic denke van Calvyn betcken nic net 'n versubjektivering van dic tcologic nic maar hou ook dic disintcgrasic van dic tcologie in. Dic cenheid van die openbaringsakle van subjek (God) na dic objek (mens) gaan verlore, want dic subjek is nic mecr nct vamuit dic openbaring kenbaar nie maar vanuit dic mens (Godsbewyse), Icrwyl dic heil in dic openbaring as Skrif ook rasionecl kenbaar is maar ecrs gerealisecr word deur 'n aparte geloofsakte as vertroucnsaktc van dic menslike wil. Gevolglik kan geloof nic meer, soos by Calvyn, as kennis wat vertroue skep, of as kennende vertrouc omskryf word nic maar net as vertrouc. Só disintegreer die komponente van die gelool en word net die subjektiewe komponent (vertrouc) behou. In die teologiese 


\section{Afbuiging van Calvyn se denke}

ant ropologic korrespondecr hicrdic disintegrasic van dic geloolsbegrip met 'n disintegrasie van die mens se psigologiese vermoens: dis nou moont lik on God waarlik te ken (nit die natuur en bevestig denr die Sko il) sonder om te glo - iets wat volgens (alvyn onmoontlik was. Natuurlik het Calvyn onk van 'n 'historiesc geloof geweet maar sou nooit gedroom het om dit as ware Godskemis te kwalifisece nie. Hoewel dic geloof nou slegs as vertroue, as wilsakte omskryf word (Ames) word dit tog op subticle wyse deur dic rasioncle omrank. Immers, om tot dic geloofsakte te $\mathrm{kom}$ is die kcmnis van God uit dic natuur en ook nit die Skrif, waar die heil vir ons as 'n moontlikheid wat Christus verwerf het in die program van 'n heilsorde aangebied word, onontbecrlik. Verder, om te weet dat jou geloof nic net kemis is nie maar egte geloof, het iy weer die rede nodig om uit die vrugte van die geloofen jou eic bevinding en ervaring (sclfs nit jou voorspocel en rykrkom!) tot die egt heid van die geloof en die sckerheid van jou verkicsing te konkludecr (praktiese sillogisme).

Ten diepste het dic openharing as npenbaring, as selfonthullende daad van die drie-enige (jod in die I7de ceu van karakter verander en val daarmec saam die aksent weer op dic kennende, willende, voclende mens. 'Subjek' en 'objek' verander van posisic. (God word non 'n bewysbare objek en dic heil 'n realiscerbare grootheid.

\section{BIBLIOGRAFIE}

AMES, W. 1639. Conscience with the power and cases thereof (geen uitgewer). (Faksimilecheruitgawe 1975 deur I'heatmm orbis terrarum, Amsterdam en Walter, J. Johnson, Inc. Norwood, N. Y., no. 708 in die recks 'The English Experience.)

BARTH, P., NIESEL, G. 1957. Opera Selecta Calvini, München: Kaiser. BE $\Lambda$ RISSI,EE III, J.W. 1965. Reformed I)ogmatics Michigan: Baker Book House.

BIZER, E. 1963. Frihortodoxsic und Rationalismus, 7urich: EVZ.

BREW $A$ RI), I. ed, 1970. 'The work of William Perkins $\Lambda_{p}$ pleford, Abingdon, Brokshire: Sutton Courtenay Press.

CHAI.KER, W.H. 1961. Calvin and some seventecnth century English ('alvinists - a Comparison of their thought ... (Ph.J)-procfskrif, DukeUniversitcit.)

(ALIVYN, J. Institutes of the Christian religion (vert. H. Beveridge). FLEMIN(;, W. 1973. Arts and idcas. 3de druk. Lonrlon: Holt, Rinchart \& Winston. 


\section{Schulx.e}

HUGHES, PHILIP E. 1965. The theology of the English Reformers. Grand Rapids: Eerdmans.

JONES, R.F. 1962. The humanistic defence of Iraming in the miclseventeentl Century (in Reason and the Imagination. London : Routledge \& Kegan Paul.

MAI.AN, C.J. I981. Dic nadere Reformasic Potchefstroom : PU vir CIIO. PFRKINS, W. 1606 . The whole treatise of the cases of conscicnce. John Legat. l'aksimilec-nitgawe 1972 deur 'Vheatrum orbis terrarum, Amsterdam en Da Capo Press Inc., New York.

REUTISR. KARI. 1940. Wille'lm Amesiusder fuilurende Theologerlescrwachenden relormierten Piet ismus. Moers : Neukirchen.

SCHULZE, L.F. 1981. Dic beginsel van die wetenskap: Calvyn en ons. PU $\operatorname{vir}$ (MHO).

'IORRANCE, J.B. 1980. Calvin and Purit anism in England and Scotland, UP. (Lcsing gehou by Int. Calvynkongres.)

TORRANCE, T.F. 1964. Knowledge of God and Speceh about God in Calvin, (in: Regards contcmporaines sur Jean Calvin, Parys : Presses universitaires de l'rance. p. 140-160.)

VAN BAARSELL, J.J. 1975. William Perkins. Amsicrdam : 'Ton Bolland. VAN DER WOUIDE, C. 1964. Op de grens van Reformatic en Scholastick, Kanıpen : Kok.

WILLLY, BASII. 1934. The scventcenth century background. Studies in the thought of the age in relation to poctry and religion. London : Chatto and Windus. 